is what is needed to get people to move really vigorously on the energy problem); it is, rather, the many technical errors in the book, some of which are inexcusable. For example, the authors claim that only 30 percent of the energy in coal is preserved when coal is gasified. But when one refers to the original paper cited for this claim, one finds the conversion into gas is 30 percent inefficient, not 30 percent efficient. Or, in their discussion of the energy required to desalt sea water, they imply that the heat of vaporization of water affects the attainable efficiency: in fact, any process can be made to approach the thermodynamic limit of $3 \mathrm{kwh} / 1,000$ gallons if enough equipment is used.

These are details which suggest that the authors should have taken more time in preparing their book. But there are two very major matters of principle in which the book is mistaken: here I quarrel not so much with the authors as I do with the very prestigious National Academy of Sciences report Resources and Man (NAS Publ. No. 1703, W. H. Freeman, San Francisco, 1969) from which The Energy Crisis draws very heavily.

The first point is the role of the breeder as an ultimate source of energy-in particular, the amount of the earth's uranium and thorium that can be made available in breeder reactors. The authors take uncritically the figure of 660,000 tons of uranium as the available nuclear fuel even if the breeder reactor is used, and they conclude from this that energy from breeders would last no more than 275 years. But this is a gross misunderstanding of the situation (one which the NAS report did not make perfectly clear). Because the breeder uses uranium so efficiently, it can, in principle, eventually use the residual uranium and thorium in the granitic rocks. The energy content of these rocks is immense-larger than the energy content of the lithium in the rocks (needed for deuterium-tritium fusion) and even comparable to the energy content of the deuterium in the sea.

The other point has to do with the substitutability of one metal for another, in particular of aluminum for copper. Here the authors claim to quote the NAS report on the world's resource of copper and Dennis Meadows (Meadows, D. H., D. L. Meadows, J. Randers, W. W. Behrens III. The Limits to Growth, A Report for The Club of Rome's Project on the Predicament of Mankind, Universe Books, New York, 1972.) on the amount of aluminum. The NAS report can in fact be faulted for being unclear on the matter of substitutability, though not on the amount of aluminum in the earth; Meadows is dead wrong in counting only the bauxites. The authors properly point to the huge amounts of copper that will be needed to generate tomorrow's electricity. To them the impending shortage of copper presents an all but insoluble limit to the growth of energy. They dismiss rather casually the possibilities of substituting aluminum for copper; yet this is the essence of the matter. Aluminum is the most abundant metal in the earth's crust. Should we run out of copper, we shall certainly turn to aluminum, with little loss in the efficiency of generation and transmission of electricity.

A little knowledge is a dangerous thing. And when little knowledge is brought to the analysis of such an immensely important matter as the current energy situation, the result is a misleading and confusing book. These words, I believe, are justified in describing The Energy Crisis.

\section{DIRECTOR}

Alvin M. Weinberg

\section{OAK RidGe National LABORATORY}

OAK RIDGE, TN 37830

(Operated by Union Carbide Corporation

for the US Atomic Energy Commission)

\title{
Ecology of a Clan-Cluster in New Guinea's Central Highlands ${ }^{1}$
}

Our growing concern for better understanding of the positions of human societies in ecosystems impels us to search for baseline measurements among the anthropological surveys of primitive peoples. Surveys made from the viewpoint of the archacologist, that is, building the evidence of the economy into a functional explanation, provide valuable insights into the role of man in ecosystems he occupies. The Central Highlands of Australian New Guinea still hold neolithic agriculturalists who have had contact with a few materials of industrialized society (steel axes and knives) no more than 30 years. In the early 1960's anthropologist A. P. Vayda initiated a study of "Culture and Environment in the New Guinea Rainforest" to which was joined an anthropological-geographical research project titled "Human Ecology of the New Guinea Rainforest." A major result of the anthropological study has been the very informative book by Roy A. Rappaport (1967), Pigs for the Ancestors, concerning ecologically adaptive functions of ritual and social be-

${ }^{1}$ Clarke, William C. 1971. Place and people. An ecology of a New Guinean community. University of California Press, Berkeley, Los Angeles, London. xiv +265 pp., 9 tables, 9 maps, 10 figures, and 34 photos. $\$ 9.00$. havior among the Maring peoples (see review in this journal by Niering, 1969, Ecology 50:162).

The geographers of the research team, John M. Street and William C. Clarke, conducted field investigations in 1964 and 1965 to extend the information base on vegetation, agriculture, climate, soil, and the relations of these to population sizes. Place and People is Clarke's doctoral dissertation "transmuted into something approaching a generally readable book," as he puts it. It is not only an eminently readable book, but a straightforward account of excellent observations on a small community of 154 persons, the Bomagai-Angoiang, at the point in time when Western Civilization has begun to alter their ways of life. The author is under no pressure to explain the behavior and beliefs of the people. He describes how they live and support themselves, ordering the details in terms of the components of ecosystems. The resulting study is remarkable for its clarity, objectivity, and insight into the lives of these people, who are archetypal agriculturalists.

The montane basin, named the Ndwimba Basin by the author, is topographically somewhat isolated from the main slopes of the Simbai Valley, which are occupied by the Maring-speaking peoples from the foot-slopes to 
near the mountain crests; thus the Ndwimba Basin and the Bomagai-Angoiang group form a natural and prettymuch closed unit. The book's opening chapter describes the people, the geographic setting, and the general features of the natural resources. A long second chapter methodically probes the details of the Ndwimba Basin ecosystem, revealing man's pervasive influence and the responses of the total system to his occupancy. No biologist could come to an understanding of the vegetation composition and structure without knowledge of the human occupancy in the depth provided here. In the third and final chapter the author describes daily sequences in the lives of individuals and families, so that the reader can appreciate the diurnal rhythms and the rather weak seasonal rhythms (important only for starting taro and yam gardens, during the June to September drier period, the "time belong sun") in the lives of the people. Bomagai-Angoiang knowledge of the useful plants is not limited to the usable parts but includes the life histories and forms of vegetative reproduction as well.

There are four appendixes. The first is an essay which groups together comments on several theoretical and practical problems including the application of the ecosystem approach to studies of human societies, validity of geographic analysis of microregions, and difficulties of communicating with the Bomagai-Angoiang through interpreters. The second is an annotated list of spontaneously occurring plants; the third, an annotated list of cultivated plants; and the fourth, a short enumeration of wild animals having some significance in the daily lives of the people. The plant lists, containing the information the author was able to muster from available sources, are not important as contributions to the botany of the area, but they are valuable for the annotations regarding relations to the human population. A useful bibliography of regional and general references is provided. The general presentation is effective, with the minor exceptions that reference is made to a "Plate 5" which does not appear in the book, map 3 lacks a north arrow, and the photographic illustrations are neither numbered nor indexed.

The author's perceptive and objective observations of human activity in the context of the Ndwimba Basin ecosystem make this an important contribution of facts, many of which are quantified to the extent they are usable in comparisons with other ecosystems and in measurements of change with passage of time. We believe this book will be used currently and over the long range by a wide variety of specialists in the social, biological and geographical sciences. On a more personal level, we would add that this volume greatly improved our understanding of the human influence on the montane forests of the New Guinea Highlands which intrigued us during a recent visit. We recommend this volume very highly both for the facts and interpretations it conveys and for the reading pleasure it affords.

William S. and ANne S. Benninghoff

DEPARTMENT OF Botany

THE UNIVERSITY OF MichigaN

Ann Arbor, Michigan 48104

\section{Historic Popular Ecology 1}

This is an unusual book, written and first published (1957) before ecology became a household word. It is a skillful blending of American art, poetry, and literature produced over three centuries to portray the unfolding ecological and conservation scene in a public frame of reference which has reached a crescendo in the early 1970 's. It traces public attitudes toward nature as expressed in popular publications regarding utilization, appreciation, and enjoyment. Emphasis is given to the extremes-the total neglect of nature on one hand and a healthy respect for nature on the other. The theme is the relationship between man and nature with the necessity for a harmonious relationship which in recent years only has reached the general public after many years of exhortations by enlightened naturalists. From a few strong voices in the wilderness, there has developed an awareness on the part of the general public of scenic beauty, the economic value of natural resources, and the role man plays in the balance of nature.

In 64 plates, the author illustrates ways in which the American public was influenced in its concern for nature through paintings and photographs during the 19th and first half of the 20th century. In addition, there are 17 sketches based largely on old wood cuts and an appropriate vignette at the beginning of each chapter. The writings of John and William Bartram, Benjamin Frank-

${ }^{1}$ Huth, Hans. 1972. Nature and the American. Three centuries of changing attitudes. Bison Book Edition, University of Nebraska Press. 250 p. $\$ 2.95$ (paperback). lin, Thomas Jefferson, C. S. Rafinesque, Louis Agassiz, Charles Lesueur, among the scientifically minded, the poetry of Walt Whitman, William Cullen Bryant, Edgar Allan Poe, and the literary productions of James Fenimore Cooper, Ralph Waldo Emerson, Henry D. Thoreau, and Nathaniel Hawthorne, among others, are brought to bear upon the education of the American public toward an intelligent view of nature.

The pioneer naturalists, Mark Catesby, George Catlin, Alexander Wilson, John J. Audubon, John Burroughs, and John Muir, pointed the way for later naturalists and, eventually, for concerned citizens in the appreciation of nature. The development of the national parks is traced to show their influence on an awakening interest in nature by the laymen.

A special chapter is devoted to "The Theodore Roosevelt Era" with its pioneers in public forestry and conservation. The contributions of Gifford Pinchot, Frederick L. Olmstead, and Ernest Thompson Seton, along with Burroughs and Muir, played a leading part in the development of government policy. A concluding chapter on conservation brings the story up to date including some of the contemporary leaders in resource preservation and conservation.

My chief criticism of the work is an over-stress on the popular appreciation of nature and not enough attention given to the serious students of natural history and its modern successor, ecology. No mention is made of leadership given by the Ecological Society of America or of its out-growth, the Ecologists Union, which evolved suc- 